PIVKA-II上昇を伴い右下腹部痛で発症した肝細胞腺腫の 1 例

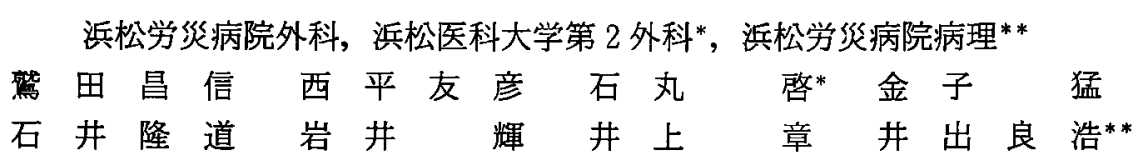

症例は24歳男性, 右下腹部痛で来院した. 超音波検查で肝右葉に腫瘍性病変を認めた. $\mathrm{CT}$ 上まだらな造影効果を受け，星芒状の低吸収域を有する腫煬が右下腹部まで発育し

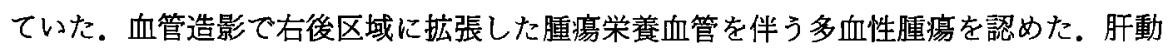
脈造影下 CT で全体として結節単位で漂染された。血管造影でみられた拡張, 届曲した 血管は腫黈辺縁を走行し, 内部で求心性に走行する動脈には拡張, 屈曲を認めなかった。 画像上肝細胞腺腫が強く疑われた. HBV, HCV は陰性だったが, PIVKA-IIが5,700 $\mathrm{mAU} / \mathrm{ml}$ と高值で肝細胞癌を否定できなかった. 肝右葉切除を施行した. 正常肝に発生 した $21 \times 9 \times 8 \mathrm{~cm}$ の腫旿で, 割面で色調は黄褐色で出血巣を認めた。病理診断は肝細胞 腺腫だった. 切除後 PIVKA-II は正常化した. 右下腹部痛で発症し PIVKA-II高值を呈 した特異な肝細胞腺腫の 1 例を報告した。

索引用語：肝細胞腺腫, PIVKA-II, 肝動脈造影下 CT

\section{はじめに}

右下腹部痛で発症し, PIVKA-II上昇を伴った肝細 胞腺腫の 1 手術例を経験したので報告する.

$$
\text { 症例 }
$$

症例：24歳, 男性.

主訴: 右下腹部痛。

家族歴：特記すべきものなし.

既往歴：生来健康で, 蛋白同化ホルモン等の服用歴 はない.

現病歴：1997年11月29日笑右下腹部痛が出現し た。痛みが軽快せず，12月 1 日当院を受診した。

来院時現症: 身長 $169 \mathrm{~cm}$, 体重 $52.5 \mathrm{~kg}$. 体温 $37.1^{\circ} \mathrm{C}$, 脈拍 $64 /$ 分, 呼吸数 $14 /$ 分. 右下腹部に圧痛, Blumberg 徴候を認めた。

来院時血液検查成績：W B C $17,900 / \mathrm{m} \mathrm{m}^{3}$, $\mathrm{RBC} 469 \times 10^{4} / \mathrm{mm}^{3}, \mathrm{Hb} 15.1 \mathrm{~g} / \mathrm{dl}, \mathrm{Ht} 45.7 \%$, Plt27.8 $\times 10^{4} / \mathrm{mm}^{3}$. 生化学椧查で CRP18.3mg/d と 上昇を認めた。その他，肝機能検查を含め生化学検査 に果常は認めなかった。

2001 年11月14日受付 2002 年 2 月 28 日採用 〈所属施設住所〉

干430-8525 捠松市将監町 25
腹部超音波検查所見：肝右葉を占拠する結節状の高 エコーと低エコー領域が混在する腫瘍性病変が認めら れた (図 1).

入院時の腫瘍マーカー：CEA0.5ng/ml $(<2.5)$, CA19-9 $6 \mathrm{U} / \mathrm{ml}$ 以下 $(<37)$, AFP1.0ng/ml 以下 $(<$ 2.5)は正常範囲であったが, PIVKA-II (EIA)は5,700 $\mathrm{mAU} / \mathrm{ml}(<100 \mathrm{mAU} / \mathrm{ml})$ と上昇していた. $\mathrm{HBV}$, HCV は陰性だった.

Cefazolin の投与を開始し, 入院 2 日後には腹痛は 消失し炎症所見も鎮静化した。

CT 検査所見：単純で腫愓はほ等吸収域で, 内部 に低吸収域を認めた(図 2 a). 肝左葉は代傥性に肥大 していた。造影ではまだらな造影効果を受けるほほ等 吸収の腫瘍性病変で内部に星芒状の低吸収域を認めた

(図 $2 \mathrm{~b}$ ). 冠状断で腫㰾は右下腹部まで発育していた (図 2 c).

血管造影所見：右肝動脈後区域枝は全般に搪張して いた，右後区域に拡張・屈曲・蛇行する血管を伴う多 血性腫揚を認めた（図 3 ).

肝動脈造影下 CT 所見：腫湯全体が各結節単位で賑 染され, 内部に隔壁様・星芒状の低吸収域を認めた。 腫場辺縁を買いて中心部に向かう拡張した右後区動脈 の分枝や（図 4 a)，辺縁を走行する拡張・屈曲した動 


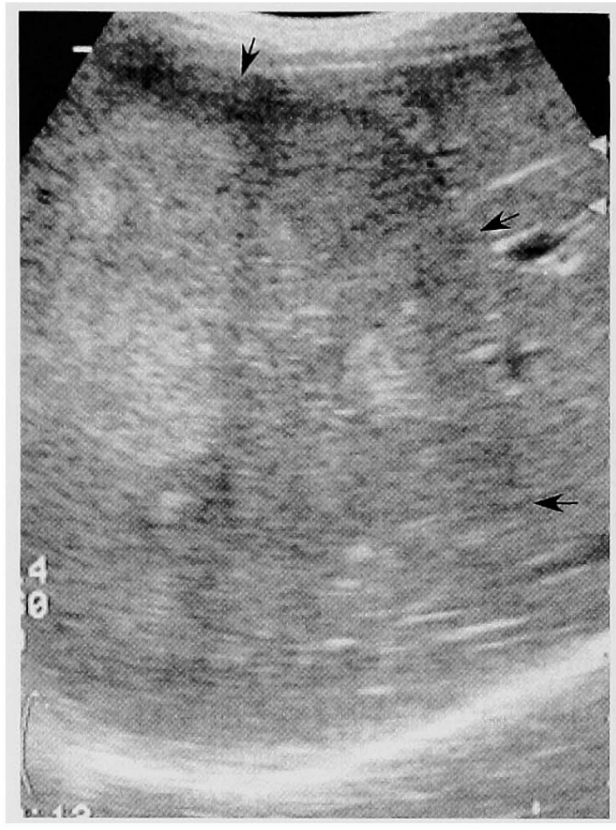

図 1 腹部超音波検査所見：肝右葉に結節状の 高エコーと低エコー領域が混在する病変が認 められた。矢印は腫湯辺縁を示す。

脈が描出された（図 $4 \mathrm{~b}$ )，腫漡内部の動脈は求心性に 走行し，拡張および屈曲も認められなかった。肝癌発 生の危険因子もなく画像診断より肝細胞腺腫を疑った が, PIVKA-IIが高值で肝細胞癌を否定できなかった。

手術所見(12月22日)：腫場は右葉後区域を中心に周 囲を圧排するように存在した。非腫湯部の肝実質に慢 性肝炎や肝硬変の所見は認められなかった，肝門部で 右グリソン鞘を一括遮断して肝右葉切除を施行した。

切除重量は1,050g.

切除標本肉眼所見：弾性軟で大きさは $21 \times 9 \times 8$ $\mathrm{cm}$ (図 $5 \mathrm{a}$ ). 割面の色調は主として黄褐色で出血巣を 認めた（図 5 b).

病理組織所見：異型性の乏しい肝細胞の単調な堌殖 から構成されていた，異常な筋性血管の介在が見られ た。胆管成分は確認できなかった。肝細胞腺腫と診断 した (図6). 術後経過順調で術後29病日に退院した。 切除後 PIVKA-II（ECLIA）は $29 \mathrm{mAU} / \mathrm{ml}(<40)$ と 正常範囲に低下した。 3 年10力月を経過したが, 現在 無再発建存である。

\section{考 察}

肝細胞腺腫は稀な肝良性腫煬である，欧米では経口 避好薬との関連が密接で $90 \%$ で女性に発生する1). 本 邦では経口避妊薬とは無関連の特発性肝細胞腺腫
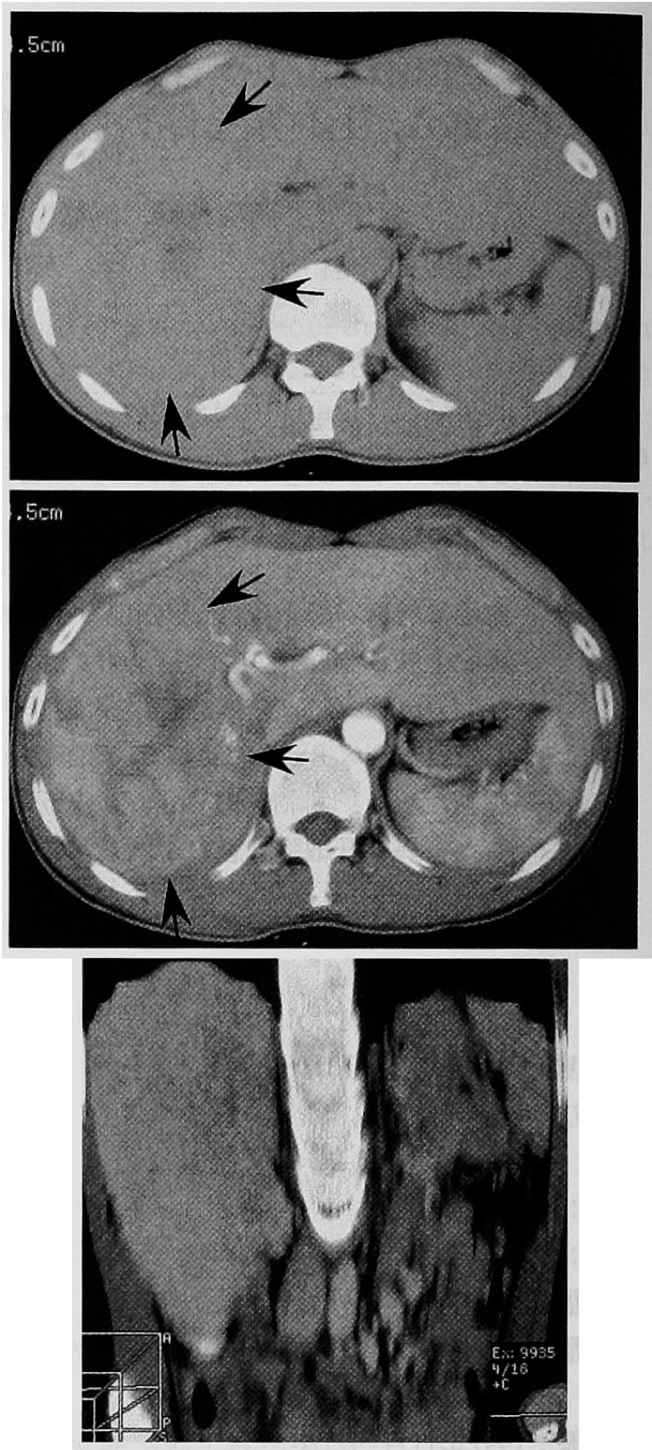

図 $2 \mathrm{a}$ 単純 CT 所見：腫演は等吸収域で,一部に低 吸収域を認めた。矢印は腫瘍辺縁を示す.

b 造影 CT 所見：腫瘍はまだらに造影効果を 受けるほほ等吸収の病変.内部に星芒状の低吸収 域を認めた. 矢印は腫瘍辺縁を示す.

c 造影 CT 所見（冠状断）：腫場は右下腹部ま での発育を示した，腫㴼下縁の小さな高吸収域は 右腎下極.

$\frac{a}{b}$

(spontaneous hepatocellular adenoma) が多い22. 男女比についても，われわれが1984年からの症例報告 を検索し検討したところ，19歳から44歳まての成人で も男性例が $37.5 \%$ を占めていて欧米ほどは男女差が顥 
著ではない。

肝細胞腺腫は結合組織に乏しく, 薄い壁で形成され る㹡張した毛細血管よりなる sinusoid を多く含み圧

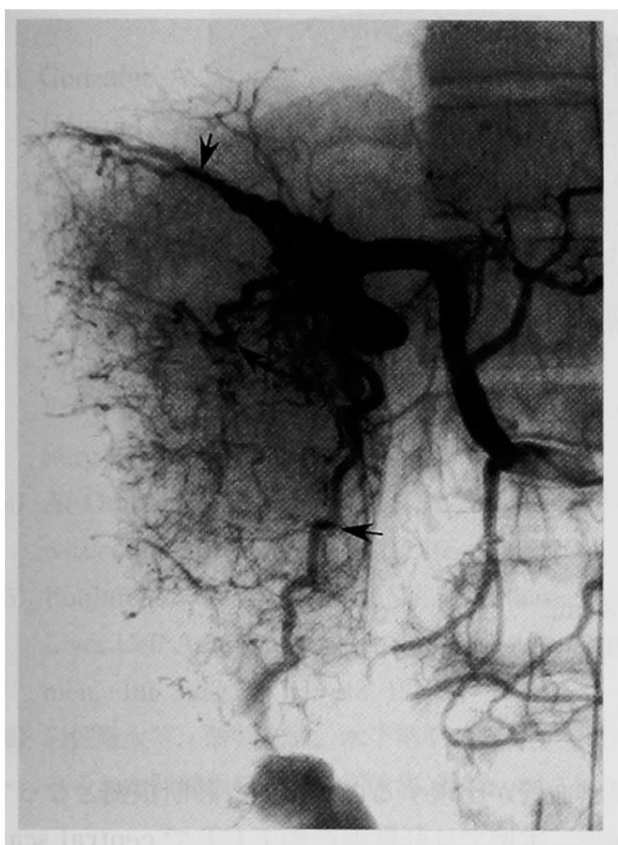

図 3 血管造影所見：右肝動脈後区域枝は全般 に㹡張していた。㹡張·届曲·蛇行する血管 (黒 矢印）を伴う多血性腫愓を認めた。
力の高い動脈支配を受ける多血性腫瘍である゙．この ため，しばしば腫漡内"や腹腔内影に出血し突然の痛み の出現に関与する．本邦では肝細胞腺腫の $16 \%$ が腹痛 で発症している ${ }^{6}$. 痛みの部位は右季肋部が多い(46). 右 下腹部痛で発症した症例はわれわれの検索しえた限り では右下腹部に達する有荎性の肝細胞腺腫が捻転を起 こした 1 例が報告されているのみであった7. 本例で は右下腹部まで発育し腫㿟内に出血巣を認めたので, 腫瘍内出血が突然の腹痛の発症や異常理学所見に関与 したと考えられた。

本例では, 血管造影で全体に動脈の拡張・届曲・蛇 行が目立ち肝細胞癌との鑑別が問題となった，肝細胞 腺腫は肝細胞癌と同様に腫瘍の周辺から内部に向かう 求心性の血行動態を有する ${ }^{899}$. 血管造影は二次元の描 出であり angio-CT は血管造影と比較して, 各々の腫 瘍の血管構築をより客観的に捉えられる でみられた拡張し屈曲・蛇行する動脈は肝動脈造影下 CTで腫場周辺を走行する栄養血管として描出され た.腫瘍内血管は肝細胞腺腫では細い新生血管であり, 肝細胞癌では拡張し屈曲・蛇行する腫瘍血管である99. 本例の肝動脈造影下 CT で腫場内血管は屈曲のほとん どみられない細い動脈として描出され肝細胞腺腫に合 致する所見と思われた。肝動脈造影下CTがより客観 的な肝細胞癌との鑑別診断に有用である可能性が示唆

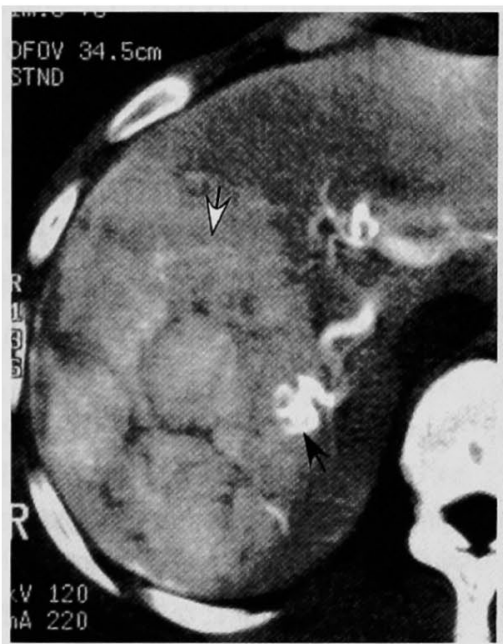

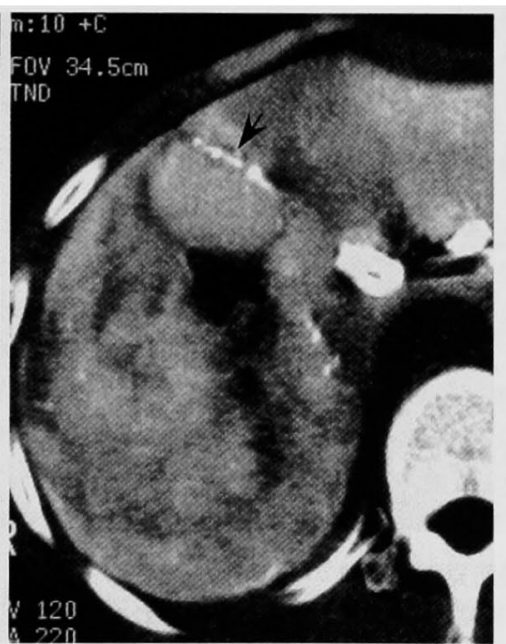

図 4 肝動脈造影下 CT 所見：a )腫瘍は結節単位で濃染された。辺縁を貫いて中 心部に向かう動脈を認めた (黒矢印)。内部の動脈は細く，屈曲をほとんど認め ない（白矢印），b）血管造影で認めた抎張，屈曲した動脈（黒矢印）は腫湯の 辺緑を走行した。 


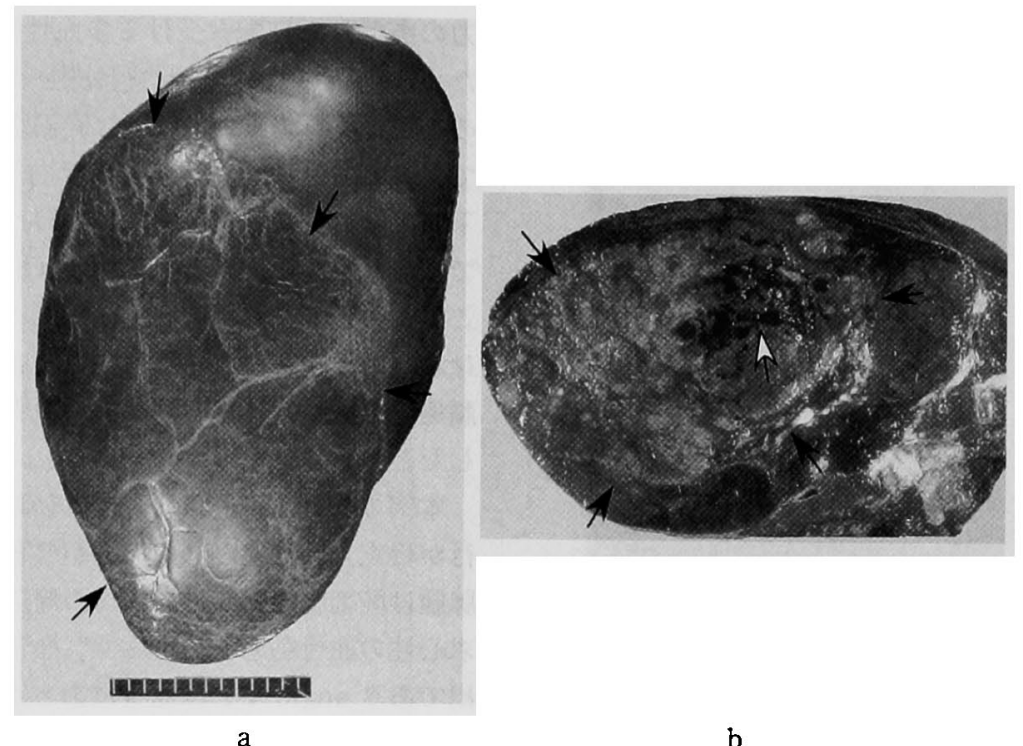

図 $5 \mathbf{a}$ 切除標本肉眼所見：大きさは2 $1 \times 9 \cdot 8 \mathrm{~cm}$.

b 割面像：色調は黄褐色で出血巣 (白矢印) を認めた。黑矢印は腫湟辺縁を 示す.

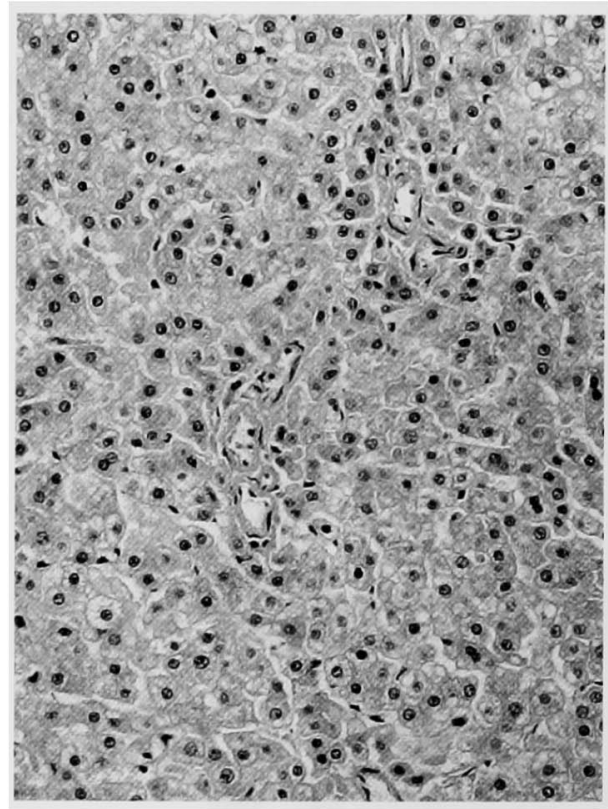

図6 病理組織所見：異型性の乏しい肝細胞の 单調な增殖. 異常な筋性血管の介在が見られた (HE 染色×2011)

された。また，本例のように central scar 様の所見を 呈する症例では focal nodular hyperplasia $(\mathrm{FNH})$ と の鑑別が必要となる．FNHでは central scarのなか
に異常血管が出現するのが重要な診断根拠となってい るが10)，本例では肝動脈造影下 CT で central scar を 思わせる低吸収領域に異常血管が認められず，さらに 求心性な血流支配であったため鑑別診断が可能であっ た。

本例では術前 PIVKA-IIが高値を示し，切除後正常 化した．肝細胞腺腫では悪性転化例を除いて通常腫瘍 マーカーが陽性になることは少ない"11.このため,肝細 胞腺腫と肝細胞癌の鑑別にしばしば腫瘍マーカー検査 が行われる.PIVKA-II值が高值を示す PIVKA-II産 生性の肝細胞腺腫の報告が見られ(112)鑑別診断にあた り念頭に置く必要がある。なお，報告例のいずれにお いても本例と同じく $\alpha$-fetoprotein は正常範囲内であ った.

Leese ら ${ }^{3)} 24$ 例の肝細胞腺腫の検討より治療につ いての詳細を報告している．経口避妊薬の中止など保 存的に経過観察するとの治療方針に対して，突然の予 測できない出血や悪性化の可能性, さらに腫瑒増大に より切除が不可能になる危険があるので，単発または 2個であれば切除を推奖している．術式は多血性で腫 湯血管が複数存在するため肝門部での阻血を先行させ た tumorectomy を推奨している。本例では PIVKAIIが異常高值を示し画像診断上でも肝細胞疸を完全に 否定できなかったため肝門部でグリソン鞘を一括遮断 
して系統的に肝右葉切除を施行した。 結 語

右下腹部痛で発症し，PIVKA-II 高値を呈した特異 な肝細胞腺腫の 1 例を報告した。

\section{文献}

1) Gonzalez A, Canga F, Cardenas F, et al: An Unusual Case of Hepatic Adenoma in a Male. J Clin Gastroenterol 19: 179-181, 1994

2）高安賢一：肝臓の画像㟝断一細小肝癌の発見から 治療まで一. 文光堂, 東京, 1991, p78-83

3) Leese $T$, Farges $O$, Bismuth $\mathrm{H}$ : Liver Cell Adenomas. A 12-year Surgical Experience From a Specialist Hepato-Biliary Unit. Ann Surg 208: 558-564, 1988

4) Al-Otaibi L, Whitman GJ, Chew FS: Hepatocellular Adenoma. AJR $165: 1426,1995$

5) Boulafendis D, Zafarnia ME, Samaan HA: Liver Cell Adenoma Presenting as Acute Abdomen. Int Surg $70: 41-43,1985$

6）岩佐隆太郎，酒井克浩，木下博明他：青年男子に みられた肝細胞腺腫の 1 切除例. 肝臓 $29: 111-$
116, 1988

7) Mooney MJ, Nyreen MR, Hall RA, et al: Hepatic Adenoma Presenting as a Right Lower Quadrant Mass. Am Surg $59: 229-231,1993$

8）巾秀俊, 幕内雅敏, 渡辺 治他： 1 年 7 力月の 経過観察ののちに切除された肝細胞腺腫の 1 例. 日臨外会誌 $49: 1056-1062,1988$

9）高安賢一：肝臓の画像診断一細小肝癌の発見から 治療まで一. 文光堂, 東京, 1991, p147-160

10）山口雅之, 土井幹雄, 鯨岡結賀 他: 切除標本上, 腫瘍内に線維性痗痕を認如, focal nodular hyperplasiaとの鑑別に苦慮した hepatocellular adenoma $の$ 症例. Liver Cancer $5: 127-132$, 1999

11）船井貞往, 康 謙三, 中居卓也他：PIVKA-II高 值を示した肝細胞腺腫の 1 切除例. 映像情報 Med30:1385-1389, 1998

12) Uto $H$, Shigehira $M$, Kawano $T$, et al : Liver cell adenoma in a young man with elevated serum PIVKA-II level. J Gastroenterol $31: 441$ $-445,1996$

\title{
A CASE OF HEPATOCELLULAR ADENOMA WITH ELEVATED SERUM PIVKA-II LEVEL PRESENTED WITH RIGHT LOWER ABDOMINAL PAIN
}

\author{
Masanobu WASHIDA, Tomohiko NISHIHIRA, Kei ISHIMARU*, Takeshi KANEKO, \\ Takamichi ISHII, Akira IWAI, Akira INOUE and Yoshihiro IDE** \\ Department of Surgery, Hamamatsu Rosai Hospital \\ *Second Department of Surgery, Hamamatsu University School of Medicine \\ **Department of Pathology, Hamamatsu Rosai Hospital
}

A 24-year-old man, who had no predisposing factors, presented with a sudden onset of abdominal pain in the right lower quadrant (PLQ). An echography showed a large mass occupying the right lobe of the liver. An abdominal CT scan revealed a large hepatic tumor with an expansive growth to the RLQ. Celiac angiography showed a large hypervascular lesion. An angio-CT showed a hypervascular tumor containing a number of nodular high-density areas concomitant with a low-density area. It also demonstrated that enlarged arteries surrounding the tumor supplied centripetal small branches, compatible with hepatocellular adenoma (HCA). Serum PIVKA-II level was as high as $5,700 \mathrm{mAU} / \mathrm{ml}$, which decreased to the normal level after resection. He underwent right lobectomy of the liver. The specimen revealed a $21 \times 9 \times 8 \mathrm{~cm}$, tan, ovoid mass, which had arisen in the nomal liver. Final pathologic diagnosis was HCA. This unusual case of HCA with a high PIVKA-II level presenting with an acute RLQ pain is presented. 